threading our way through this verbiage we find a fascinating survey of earth's living things and the strange and often bizarre devices by which they survive and reproduce.

The subjects range in scale from Amoeba and diatoms to whales. There are interesting accounts of the almost incredible reproduction of bees, the development of vision in insects and vertebrates, electric animals, the elephant's trunk and the mating of this animal. A mere catalogue of the chapter headings would give the impression of a random selection of themes, and yet, skilfully, the author manages to demonstrate that underlying all these diverse topics there is a unity: of the amazing potential inherent in protoplasm. It is, perhaps, refreshing also to find a trained biologist who can feel wonder and even awe in the filigree cell-wall of a diatom or the splendid manoeuverability of a golden eagle in flight.

\title{
JOHN CLEGG
}

\section{The World of Birds. A Comprehensive Guide to Ornithology, by James Fisher and Roger Tory Peterson. Macdonald, $\notin 55$ s.}

Two well known and widely travelled ornithologists, British and American, the latter also a noted bird artist, have here combined their knowledge and skills to produce a spectacular book. The keynote is pictorial presentation of facts and principles, with a highly condensed text. A large format has been used (ca. $12 \frac{1}{2}^{\prime \prime} \times 9 \frac{1}{2}^{\prime \prime}$ ), and a heavy paper taking text and illustrations side by side ; in nearly two-thirds of the book there is colour on every page.

The first main section is a profusely illustrated summary of various aspects of avian biology, with emphasis on evolution and geography. The specific examples in the text and in the brilliant paintings are taken from a wide range of families and from all over the world; figures of 668 species are reproduced by eight-colour lithography. There follows a shorter blackand-white section on methods of observation, including photographic and sound recording. The other colour section consists of a series of maps, on a variety of projections, showing the range of every family (sometimes subfamily). Each map is headed by a few data on the group, such as known geological age, probable geographical origin, and number of included genera and species ; and also by a silhouette of a representative form (but lacking any indication of scale). One knows the limitations of such maps, necessarily based on information not everywhere complete and inevitably suggesting a more sharply defined and uniform distribution than commonly exists. But taken broadly as diagrams these are wonderfully effective, and as a collection unique. The final section discusses the relations between birds and man, ending with a passage on conservation. To this is appended a "red list" of species with populations at a dangerously low level, and a "black list" of those believed to have become extinct since A.D. 1600

\section{LANDSBOROUGH THOMSON}

\section{Cats of the World, by Armand Denis. Constable, 30s.}

It is curious that the cat family, many of whose members are admired by all who visit zoos or, better still, see them in the wild, should have so little of their natural history recorded. As far as it is possible to remedy this, for there are still many aspects of the lives of cats to be explored, Armand Denis has done so. The author can scarcely need any introduction-at least to viewers of television-and this long needed book will, I feel sure, add to his reputation. It is magnificently illustrated, factual, well documented, and readable-no mean quality in a book of this kind. Though the 
format and the striking jacket suggest a "popular" work, there is nothing elementary or superficial about it ; and considering the lavish illustrations, it is amazing how much material about the structure, senses and habits of cats, great and small, has been fitted into a comparatively slim volume. Not the least instructive are the two final chapters, "Cats and Men " and "The Future for Cats, " the latter reminding us of the dangers which face so many living creatures today. It is typical of the author, and also very appropriate, that part of the proceeds from the sales of this book go to the World Wildlife Fund. If the other works in this special series, under the able editorship of Dr. Bruce Campbell, are as good as the first, it is nice to think that naturalists and the Fund will both derive much benefit from them.

MAXWELL KNIGHT

The Sea Otter, by I. I. Barabash-Nikiporov, V. U. Reshetkin, and N. K. Shidlovskaya. Translated by A. Birron and Z. S. Cole. Edited by P. Cohen. National Science Foundation, Washington, D.C. : Israel Programme for Scientific Translations, Jerusalem. $\$ 6.00$.

Lake Baikal and its Life, by M. Kozhov. Junk, The Hague. Guilders 35.00 .

These two works by Russian zoologists are of great interest and value, and their appearance in English is highly welcome as so much Russian work is inaccessible to those who cannot read the language.

"The Sea Otter" is an exhaustive monograph on the morphology, anatomy and biology of this very interesting marine carnivore, all the more interesting because in the course of half a century it has, through being protected, recovered in numbers from near extinction to what promises to be a viable population. There are several herds at various points in its former range which extended all round the shores of the north Pacific from Japan to California. The studies on sea otters reported here were made on the Commander Islands off the coast of Kamchatka. Here the diet of the animals consists of sea-urchins 59 per cent, molluscs 23 per cent with fish and crustacea making up only 16.7 per cent. In feeding on sea-urchins the otter scoops up five or six, or even ten, from the bottom near the shore and brings them to the surface where it floats on its back stowing the catch on its chest while it eats its prey one at a time. In the Commander Islands the Russian observers never saw the sea otters using stones as anvils for breaking the sea-urchins or mollusc shells as has been reported of the Californian herd. The book concludes with an account of the introduction and acclimatisation of sea otters on the Murman coast and with a section on the feeding and care of sea otters in captivity. The translators have achieved a very readable text though very occasionally one wonders if a technical term has gone astray, for example " octopus " which might perhaps in this context mean " squid." There is a good bibliography, both of Russian and other works. The photographic process of producing and printing the book has resulted in considerable degradation of the quality of the half-tone illustrations.

Lake Baikal is the deepest and one of the oldest lakes in the world. The pronounced endemism and specific wealth of its flora and fauna has made it of high interest to biologists. Professor Kozhov's book gives a wide survey of what is known about this remarkable sheet of water which he knows intimately, having been for many years head of the Biologo-Geographical Institute and the Baikal Biological Station of Irkutsk University. In its long history Baikal has communicated with different biogeographical regions and received immigrants from them. One of the most interesting 